\title{
Sigale-gale samosir: from the sacred to the secular Sigale-gale samosir: dari yang sakral menjadi sekular
}

\author{
Rosta Minawati and Enrico Alamo \\ Television and Film Program and Theater Arts \\ Program Faculty of Arts and Design and \\ Faculty of Performing Arts Indonesian Institute \\ of the Arts Padangpanjang \\ West Sumatra, Indonesia \\ Correspondence: \\ rostaminawati@yahoo.co.id
}

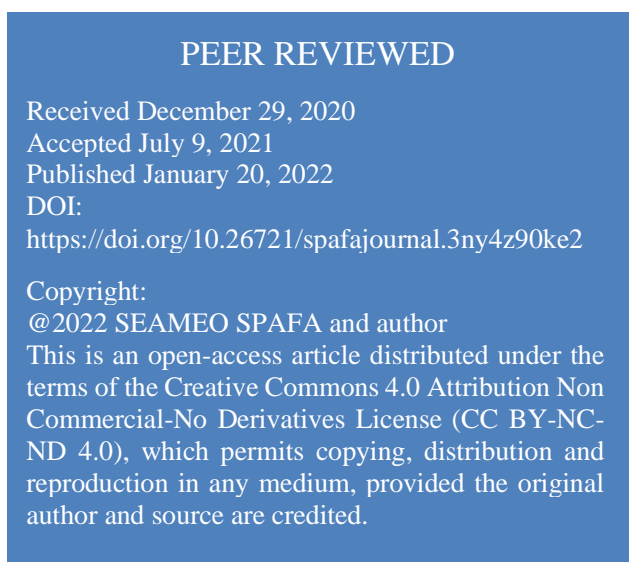

\begin{abstract}
Sigale-gale is a life-sized wooden puppet carved in the likeness of a human male. It is used during burial rituals and in modern Sigale-gale dance performances in the Toba Batak community, Samosir, North Sumatra. The traditional myth of sigale-gale has become folklore which depicts the making of a wooden statue in human form given to Raja Rahat who is ill because his favorite son Manggale died in the battle. The sigale-gale is used by the community as well in funeral ceremonies for the dead who have died childless. In contemporary practice sigale-gale has been reconceived as public performance mostly for tourists. The sigale-gale thus now functions differently socially and culturally, moving from the mythological towards the worldly. The sigale-gale dance was originally only accompanied by the music of sordam but mostly now by a mixed ensemble comprised of taganing, gong, and suling. A performance can include five to seven dancers (panortor). Sigale-gale also vary in size from human dimensions as well as smaller or even bigger. Sigale-gale in its new forms represents an effort to sustain the cultural values of the Toba Batak.
\end{abstract}

Patung sigale-gale terbuat dari kayu yang dipahat menyerupai manusia (laki-laki) digunakan saat ritual pemakaman dan dalam pertunjukan tari sigale-gale baru di masyarakat Batak Toba, Samosir, Sumatera Utara. Mitos keberadaan sigale-gale menjadi folklore yang menceritakan pembuatan patung kayu menyerupai manusia dipersembahkan kepada Raja Rahat yang sakit karena anaknya tewas di medan pertempuran. Sigale-gale digunakan pada upacara kematian yang tidak memiliki keturunan. Dalam perkembangannya, sigale-gale menjadi seni pertunjukan untuk menghibur wisatawan. Fungsi sigale-gale secara sosial budaya menjadi berbeda, yakni dari sakral ke profan. Awalnya sigale-gale hanya diiringi musik Sordam dan Sabangunan, tetapi di masa kini pertunjukan sigale-gale diiringi musik gondang, gong dan suling. Pertunjukan sigale-gale terdapat panortor lima sampai tujuh orang. Ukuran patung sigale-gale bervariasi, ada yang tinggi seukuran manusia ada juga yang memiliki ukuran tubuh lebih kecil ataupun lebih besar. Unsur pertunjukan terdiri dari: Sigalegale, musik dan tor-tor (tari). Sigale-gale dalam bentuk baru merupakan upaya pelestarian nilai-nilai budaya masyarakat Batak Toba. 
Keywords: Sigale-gale, myth, secular, Toba Batak, Samosir| Sigale-gale, mitos, sekular, Batak Toba

\section{Introduction}

This article represents an effort to present recent developments in a unique enactment of Toba Batak myth today. It is also part of a project towards encouraging new work in collaboration with Toba Batak artists. The term sigale-gale refers to both the so-named wooden articulated life-sized puppet and its performance on the island of Samosir in Lake Toba, North Sumatra Province, Indonesia. A typical performance of sigale-gale (also called manortor) is accompanied by sordam (bamboo flute) and gondang sabangunan (mixed ensemble of tuned drums, gongs and frequently a plucked chordophone). A puppeteer moves the control strings of the life-sized sigale-gale from behind so that it moves and dances to the music. In a performance there can be five to seven dancers, or even none at all. Dancers and musical numbers depend on the context of the show. Dancers serve to engage with the audience and to enliven the atmosphere. This type of contemporary performance is primarily cultural entertainment. Tor-tor (dance) can be selected according to the request of the audience who follow the manortor (dancing). Venues for such performances are found at several tourist destinations on the island including Tuktuk, Tomok, and Simanindo.

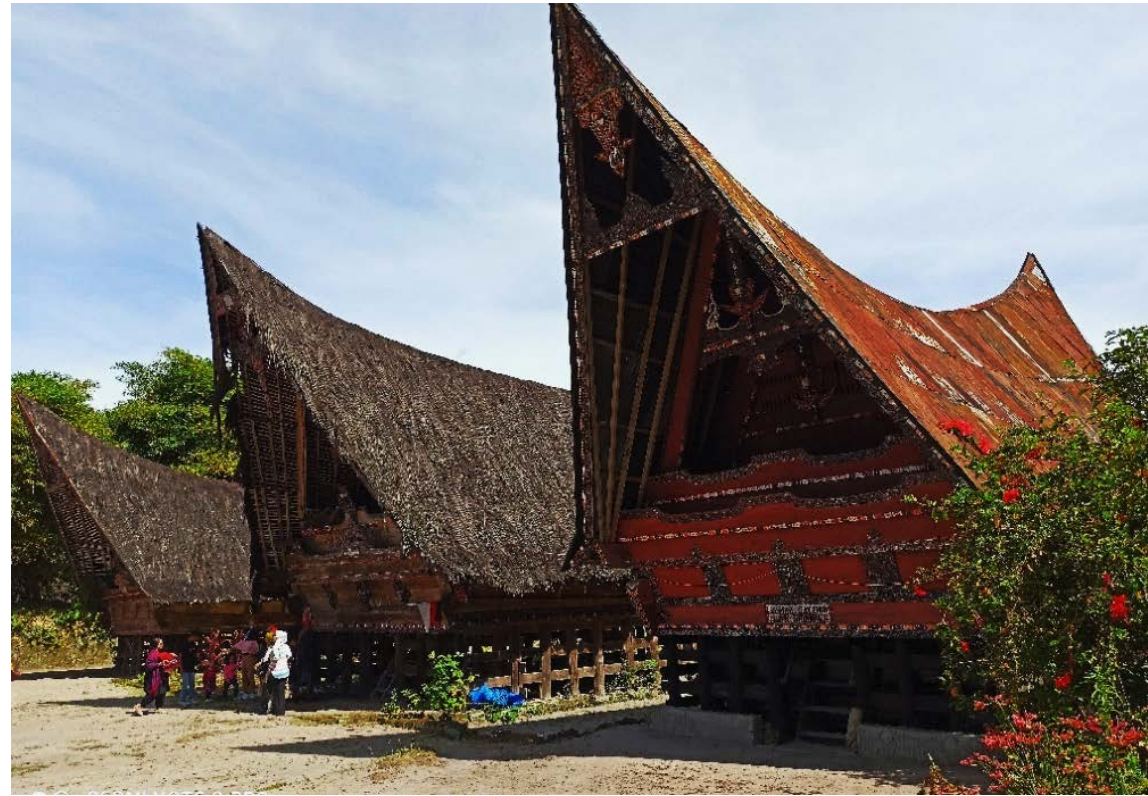

Fig. 1 Prominent tourist destination and site of sigale-gale performances Huta Bolon, Simanindo. Source: Photo by Edward Van Ness, 2020.

\section{Origins}

The original myth of sigale-gale has become a key element of Toba Batak folklore and reflects its cultural philosophy. The sigale-gale was created as an offering to a King Rahat who fell ill and despondent after his beloved son Manggale died on the battlefield (Utami 2014). The king's advisors summoned many datu (shaman), but none of them were able to heal the king. A datu advised the royal adjutant to make a wooden statue whose face was similar to the face of Manggale. The datu initiated a ritual by blowing the sordam (bamboo flute) and playing the sabangunan gondang to summon the spirit of Manggale. The puppet 
created in the image of Manggale was thus magically invested with his spirit and was carried to the palace accompanied by sordam and gondang.

Nurelide (2007) suggests the origin of sigale-gale lies in the Toba-Holbung area (North Tapanuli, on the southeastern shore of the mainland adjacent to Samosir island), and subsequently spread to Samosir Island. On Samosir, residents refer to the puppet as Raja Manggale. The sigale-gale is also still used at funerals, especially so in ceremonies for deceased individuals who are childless and whose future legacy is thus considered to be null (Nurelide 2007). In the book Batak Art and Culture (Hasibuan 1982) there is a photo of sigale-gale which includes a terse description of the performing arts and the function of sigale-gale in Papurpur Sapata, the ritual for the death of an elder who has no descendants according to H. S. Thompson ${ }^{1}$.

The sigale-gale myth is unique to the Toba Batak community, and as with all myths various versions have emerged over time. However, belief in the original myth and meaning of its existence is prevalent in the Toba Batak community. The sigale-gale as ritual performance reveals elements of the patrilineal system and philosophy in Batak Toba society, where male children are especially important in family and customary practices. The latest developments of sigale-gale, reconstructed in today's cultural context as public staged performance, have been extended and introduced outside of the Toba Lake region by various institutions and individuals, including Taman Budaya Medan, Sangar Patria, LPS Semenda, Nusindo. The prominent Toba Batak composer Ben Pasaribu (1961-2010) who actively promoted the creation of new versions of sigale-gale in the 1990's also played a role in presenting sigalegale abroad (Utami 2014).

The myth and stories of sigale-gale encompass mystical content and cultural symbols. In its construction the sigale-gale puppet has jointed wooden upper limbs mounted above a rectangular podium on wheels. The puppet is fitted with a jacket, traditional woven fabric called ulos, and a headcloth also of ulos. The sigale-gale at a funeral is performed with characteristically overt weeping, lamentations and dancing during the funeral ceremony which is called papurpur sepata. The ceremony is carried out to expiate calamity attached to death of those with no descendants, and to placate the spirits so they shall not be curious and disturb the living (Lesthia 2016).

\footnotetext{
${ }^{1}$ Discussion with H. S. Thompson, Director of Pusat Latihan Opera Batak (PLOt) Siantar [Center For The Performance of Opera Batak Siantar]
} 


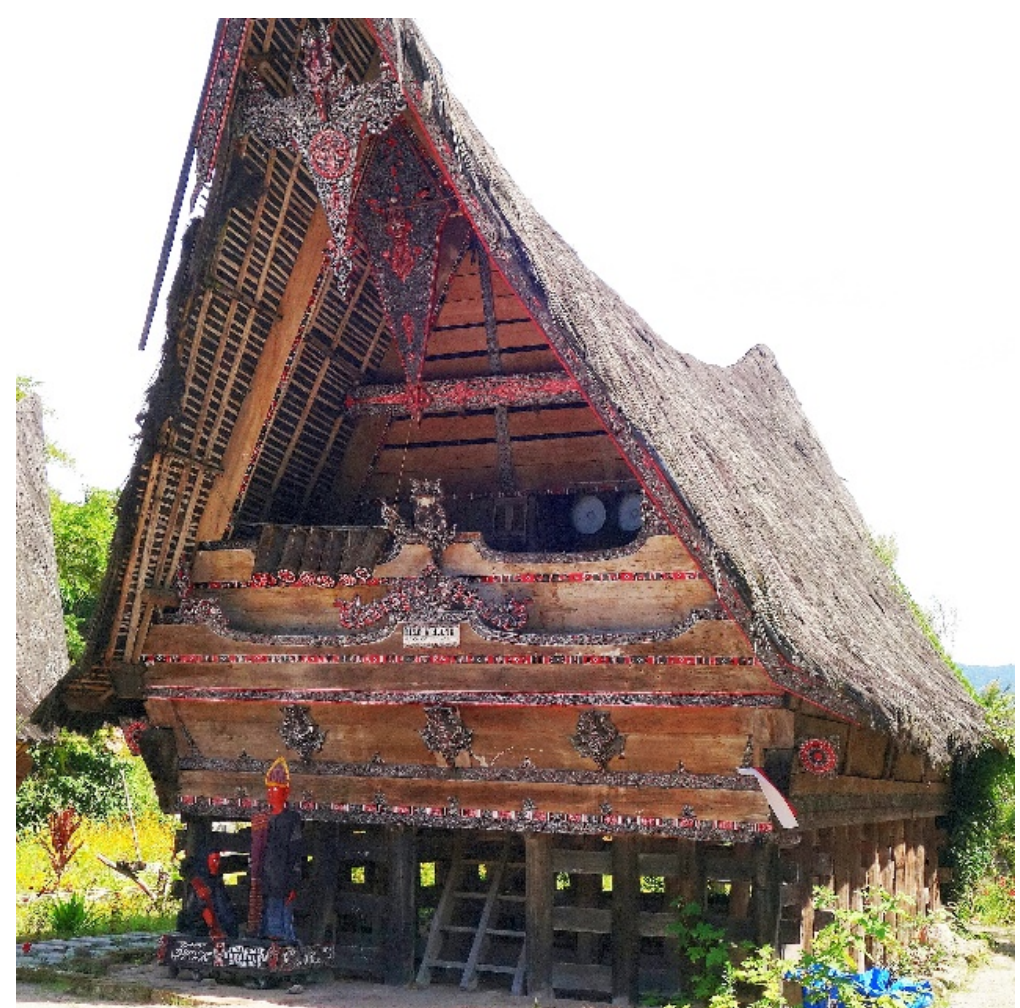

Fig. 2 Huta Bolon, Simanindo. Source: Photo by Edward Van Ness, 2020.

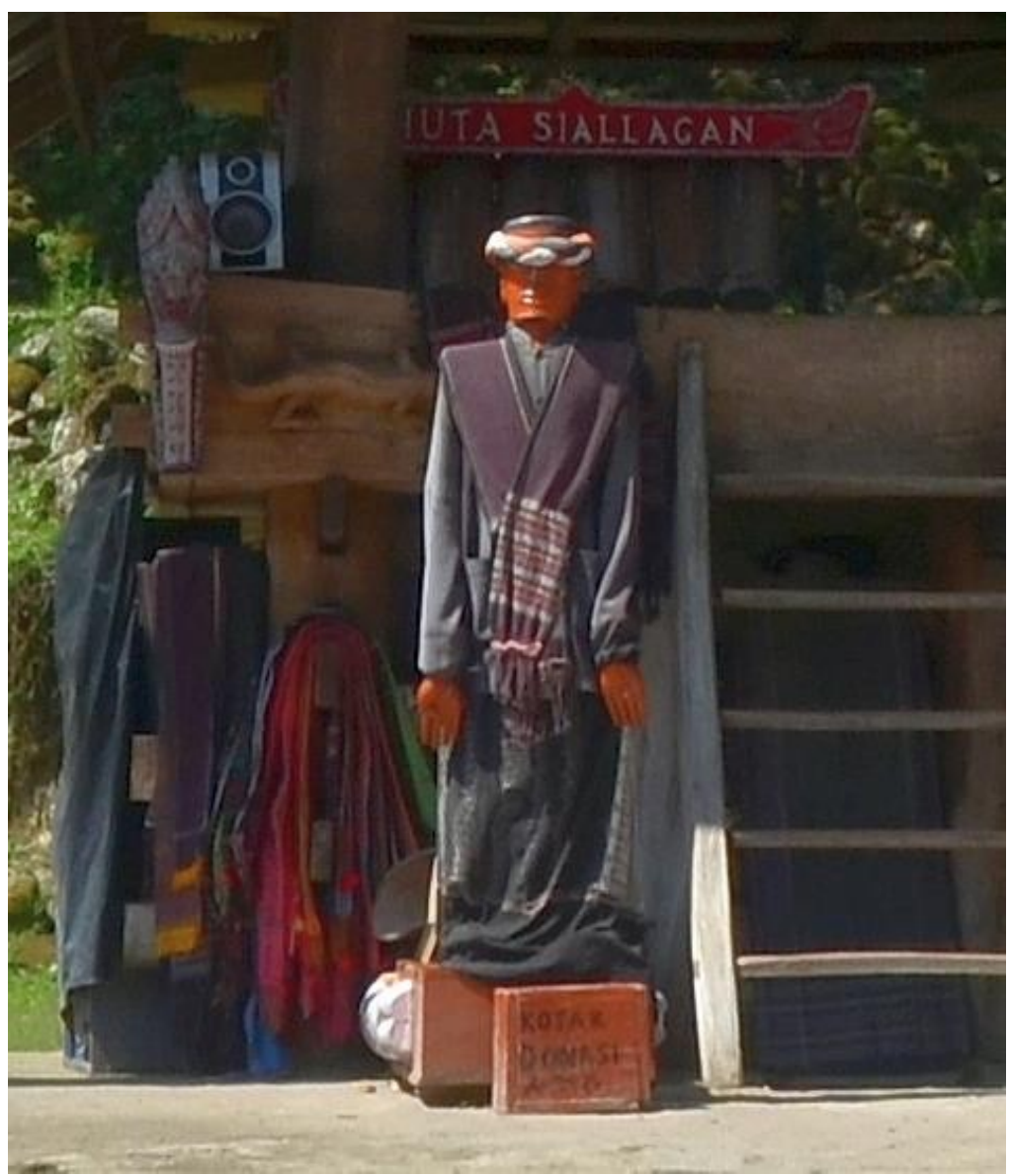

Fig. 3 Sigale-gale at Siallagan. Source: Photo by Edward Van Ness, 2020. 


\section{The Sort and Ulos}

A hallmark symbol on the sigale-gale is the sort. Sort is a headband that has three characteristic colors: white, black, red. The three colors are dominant in Toba Batak society. The other aspects of attire include a traditional jacket, draped traditional fabrics in the pattern of Ulos Ragi Hotang, Ulos Sibolang. A variant of the sort can be seen with a different wrapping of the head cloth in Figure 6.

The sort worn on the head of the sigale-gale and the ulos adorns the body of the sigale-gale. These traditional elements reflect the origin of sigale-gale as a symbolic manifestation of Mangele (King Rahat's son). Sigale-gale thus becomes a characterization of Mangele . Notably two wooden artefacts in the Yale University Art Gallery (see Figures 4 and 5 below) are labeled Si Gale Gale, one of which appears to be female (see also Tichelman 1940).

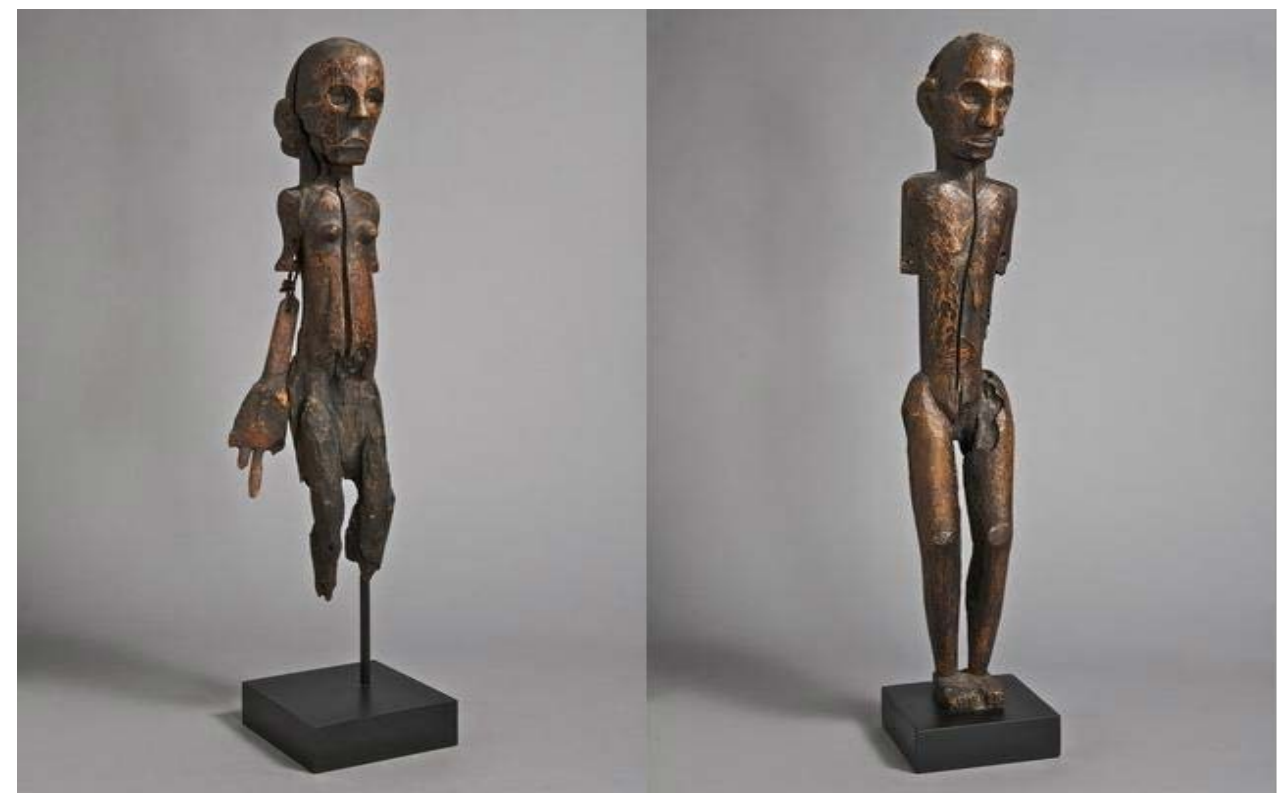

Figs. 4 and 5 Two artifacts called ‘Sri Gale Gale’, Yale University Art Gallery. Source: Johan Vipper (n.d.)

In Toba Batak mythology a site can be deemed suitable for founding a huta (village) if hariara trees (a native type of Banyan tree found on Samosir) are found on that location. For the Batak the hariara tree has magical powers, and the wood used for the construction of the sigale-gale was probably also specially chosen for its mystical qualities. Myth can begin as a process of the primordial imagination to compose a story to explain origins and situations. According to Ratna (2006), the aesthetic form of art is a manifestation of legends and myths (p. 67). The roots of the sigale-gale are legendary and mythological, but the sigale-gale as a modern performance is no longer construed a ritual reenactment of legend or myth.

The Toba Batak tribe still widely embrace a fundamental belief in spirits (parbegu) which seeks to venerate and commemorate the spirits of dead ancestors through the realization of funeral ceremonies. These ceremonies were held especially when the deceased was of high social status, such as descendants of kings and community leaders. In the belief system of the Toba Batak these practices are pursued for the purposes of connecting with their descendants in the afterlife, even summoning them to the present. In contemporary society the sigale-gale as ceremony is considered parbegu, a ceremony based on animist belief in begu ie., the spirit of a 
deceased person (Nurelide 2007). With the influx of Islam and Christianity into North Tapanuli, the animist ritual aspects of sigale gale as ceremony began to be abandoned though clearly not entirely absent in the minds of the modern Toba Batak. In fact, it is remarkable how animist belief still is quite alive as it were in the minds of not just the Toba Batak, but most Indonesians.

The sigale-gale as a wooden statue is thus believed to be a mystically-enabled vehicle for summoning the spirit of the king's deceased son. In Toba Batak society there is a persistent myth that the puppet maker will unfortunately depart precipitously from this life. It is said until now the ground podium is fashioned like a coffin wherein the puppet is also kept. In the past the puppet was considered the vehicle of spirits, said to be able to move and dance on its own. The sigale-gale moved because there was a ritual performed by a shaman (datu) who imbued the statue with a spirit. One story relates that the puppet danced for seven days and seven nights on its own without human manipulation (pers. comm. HS Thomson, October 17, 2020²).

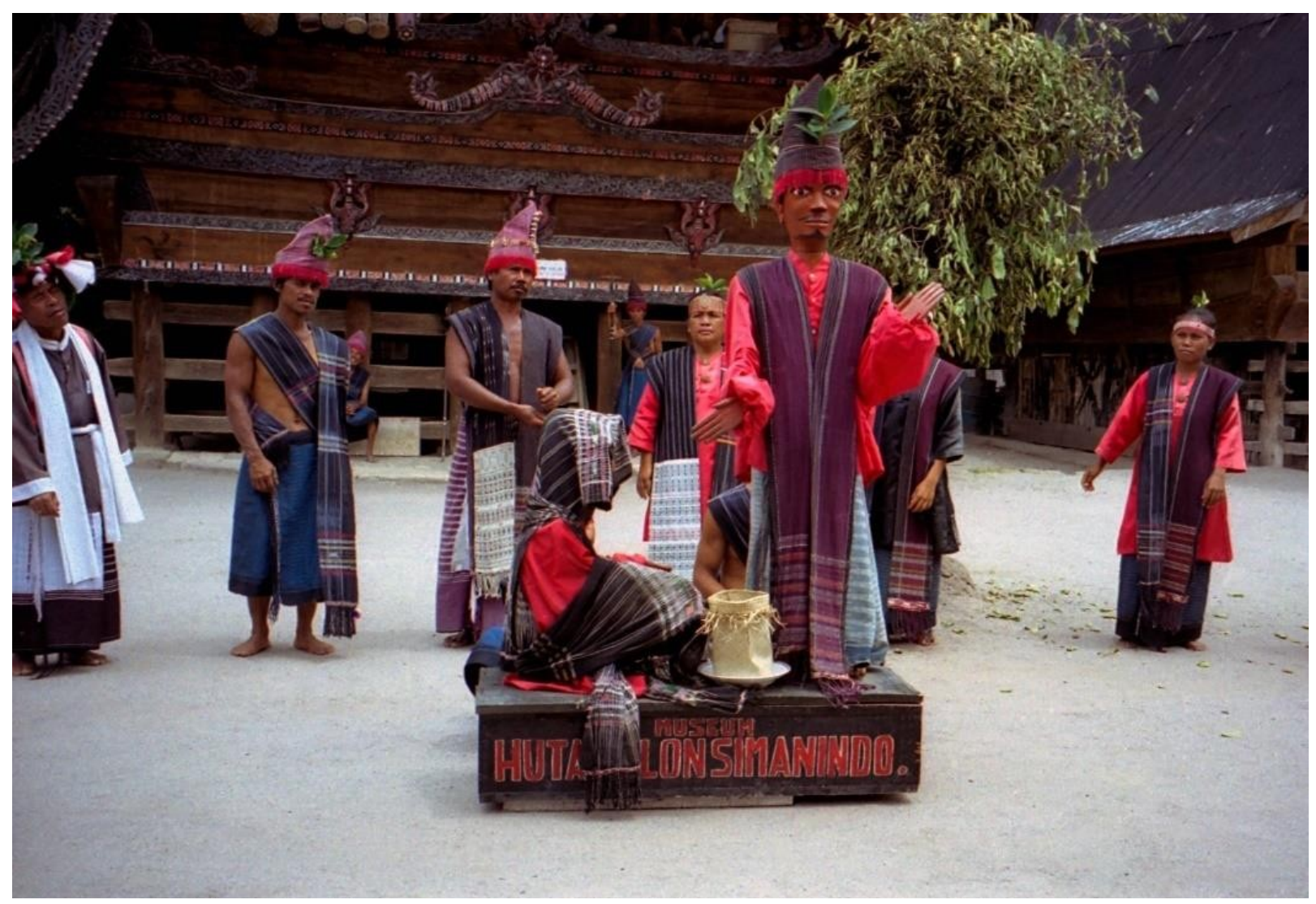

Fig. 6 Recent photograph at Huta Bolon, Simanindo. Source: Dan Lundberg (2010).

\footnotetext{
${ }^{2}$ Discussion with H. S. Thompson, 8 November 2020.
} 


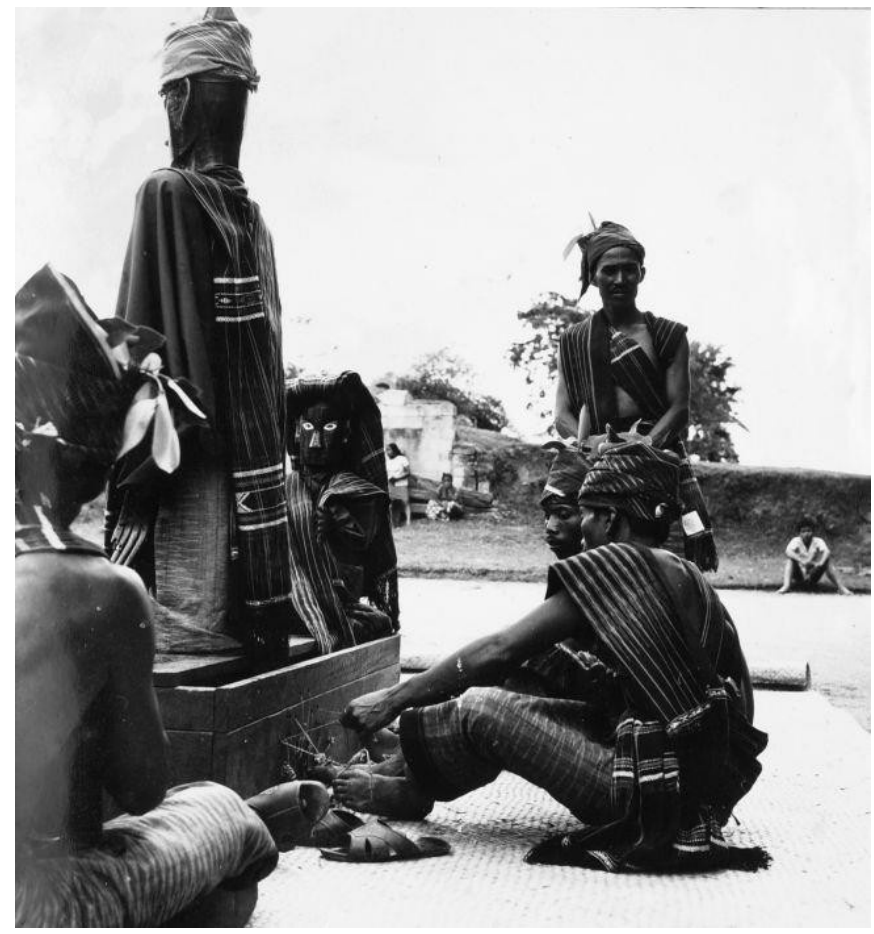

Fig. 7 'Moving the Sigale-gale’. Source: Boy Larsen (1971).

\section{Change in purpose and function}

The sigale-gale as a modern spectacle has changed in purpose and function. Legends say it functioned in death rites to comfort the king who was saddened and grieving for his son. A procession was also an integral part of that ritual. Sigale-gale now has become primarily an explicitly worldly performance for the public. Since around the 1980's it has been modified and transformed from ritual to a theatrical commodity, from the sacred to the worldly, from folklore to a contemporary construction which, though still rooted in traditional ideas, has become a public performance.

\section{Contemporary Sigale-gale}

In performances held at tourist sites, saweran (donations) are solicited and given by observers placing money directly in the pocket of the sigale-gale or in a container placed near the puppet. Donations given by visitors are not determined by the organizer of the event. Many contemporary performances also use prerecorded music rather than live musicians for reasons of convenience and minimizing costs. Yet there remain artists or art enthusiasts on Samosir who strive to maintain the traditional aspects of sigale-gale beyond mere performances. The following figure shows a modern version of sigale-gale.

As shown in Figure 8, the sigale-gale statue is similar to the Betawi ondel-ondel found in the area around Jakarta. Now performed with multiple puppets, each person moves each massive sigale-gale puppet from within and also moves through space. The shape of the sigale-gale puppet retains the very general character and style of traditional puppet. In the past sigale-gale sculptures were made of sacred wood from special trees and surely were created with spiritual practices is common in many other Indonesian cultures.

Today the choice of wood can come from any source, provided that it is aged, strong, and has a texture that is easy to carve. Creativity and innovation regarding the sigale-gale in inter-related 
aspects of form, function and purpose has led to simplifying and further stylizing the parts of the puppet contributing to a variety of representations. Modern constructions do not follow any ritual prescriptions, though one avid maker of new puppets in various sizes confides that he has had a number of curious and even frightening experiences having produced many contemporary styled puppets suggesting spiritual gravity surrounding the making of even his modernized puppets ${ }^{3}$

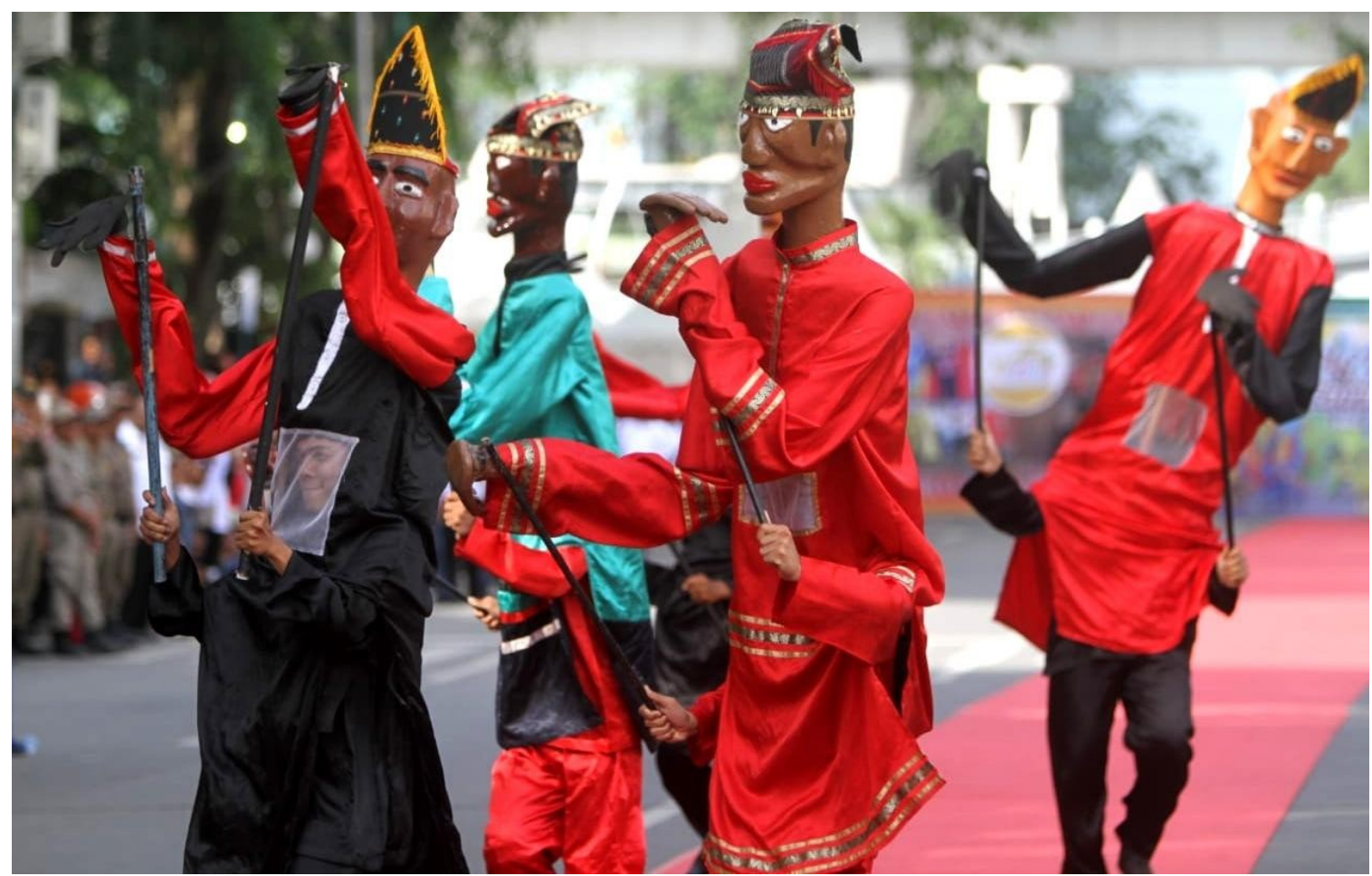

Fig. 8 Contemporary Sigale-gale by Henrizal Batubara. Source: Photo courtesy of Henrizal Batubara, 2016

The sigale-gale design is not rigidly prescribed. Variability arises from the craftsmen's interpretation and the function of use. Materials used include wood, plastic and styrofoam. While modern versions of puppets called sigale-gale are diverse the traditional puppets are still of carved wood.

\section{Modern tourist performances}

The components of the performance are normally a sigale-gale puppet, tor-tor (dance) accompanied by music on traditional instruments. Dancers' attire is simple traditional dress, prominently including the Toba Batak ulos. The dance may be regarded as a highly characteristic folk tradition with straightforward but iconic movements which carry social meaning. Sigale-gale dance choreography appears to be quite simple, enabling and encouraging anyone present to participate. The sigale-gale is stationary with dancers moving around the puppet in circular motion with the musicians in the back. Repetitive uncomplicated patterns are accessible even for the non-initiated

${ }^{3}$ These are puppets are designed and photographed by Henrizal Batubara, who described his experiences to us on 18 November 2020. 
observer. The traditional music is a specific repertoire which supports the movement and creates the appropriate atmosphere.

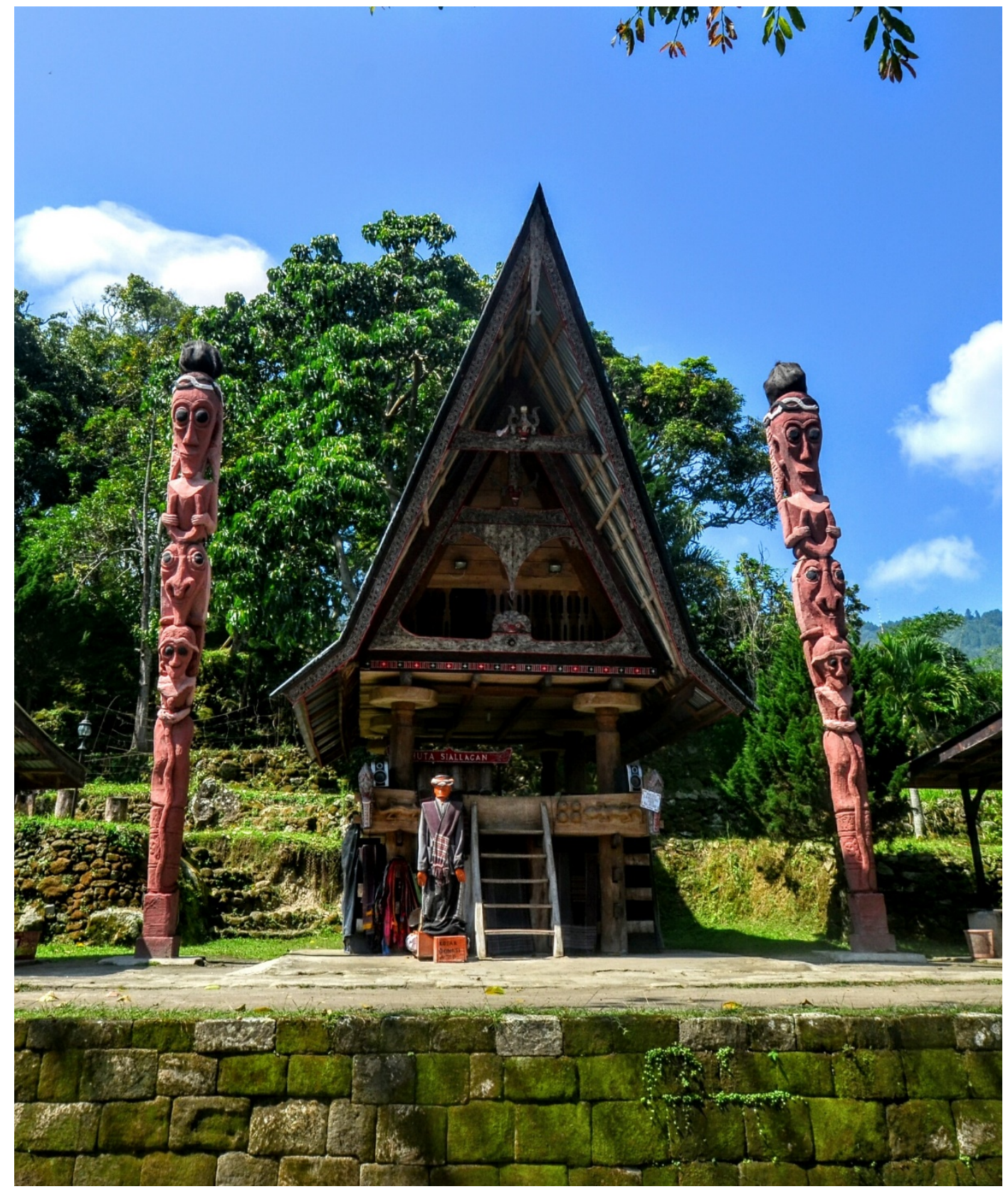

Fig. 9 Sigale-gale Huta Siallagan, Samosir. Source: Photo by Edward Van Ness, 2020.

Modern performances last about one hour, including the tor-tor, ai goarna dance, mula-mula dance, and several other dances. Typically, these are light and lively events where the audience is encouraged to join in the traditional dancing. This is not actually unusual, as the Toba Batak in fact famously dance virtually all their rituals in customary prescribed patterns. The meanings to participants are thus clearly different. Although much might seem to have been left out in contemporary form of entertainment, these performances still at a certain level have the potential to serve a meaningful reminder to young people of the traditions of the Batak past. Recent developments both on Samosir as well as in the surrounding region strongly suggest a renaissance of interest to reaffirm Batak cultural identity in contemporary times. 


\section{References}

Hasibuan, AS (1982) Batak Art and Culture. Medan: Yayasan K. J. M. J.

Larsen, B (1971) Moving the Sigale-gale. Available at: https://hdl.handle.net/20.500.11840/275932 [accessed 16 November 2020].

Lesthia, K (2016) Sigale-gale, Boneka Mistis dari Samosir [Sigale-gale: Mystical Puppet from Samosir]. CNN Indonesia. Available at: https://www.cnnindonesia.com/gayahidup/20160823153232-269-153294/sigale-gale-boneka-mistis-dari-samosir [accessed 9 November 2021].

Lundbrerg, D (2010) Sumatra Samosir Island old Batak village. Available at: https://www.flickr.com/photos/9508280@N07/5068852161 [accessed 16 November 2020].

Nurelide (2007) Meretas Budaya Masyarakat Batak Toba Dalam Cerita Sigale-gale [Deconstructing The Culture Of Toba Batak Society In The Sigale-gale Story]. PhD thesis, Universitas Diponegoro, Semarang.

Ratna, NK (2006) Teori, Metode, dan Teknik Penelitian Sastra dari Strukturalisme Hingga Postrukturalisme Perspektif Wacana Naratif [Theory, Method And Research Technique In Literature From Structuralism Till Poststructuralism From The Perspective of Narrative Discourse]. Yogyakarta: Pustaka Pelajar.

Tichelman, GL (1940) Si Gale Gale, De Bataksche Doodenpop [Si Gale Gale, The Batak Death Doll]. In: Cultureel Indie Tweede Jaargang [Cultural Indies Second Year]: 106-112. Leiden: E. J. Brill.

Utami, DE (2014). Analisis Patung Sigale-gale Versi Henrizal Batubara Di Taman Budaya Sumatera Utara [Analysis of The Sigale-gale Puppet Created By Henrizal Batubara At The North Sumatra Government Arts Center]. Undergraduate Thesis, Medan State University, Medan, Indonesia.

Vipper, J (n.d.a). Puppet (Si Gale Gale). Available at: https://artgallery.yale.edu/collections/objects/159734 [accessed 16 November 2020].

Vipper, J (n.d.b). Puppet (Si Gale Gale). Available at: https://artgallery.yale.edu/collections/objects/159735 [accessed 16 November 2020]. 